\title{
Agro-morphological and molecular assessment of advanced wheat breeding lines for grain yield, quality and rust resistance
}

Satish Kumar*, Geeta Sandhu, SS Yadav, Vanita Pandey, Om Prakash, Ajay Verma, S C Bhardwaj, Ravish Chatrath and GP Singh

ICAR-Indian Institute of Wheat and Barley Research, Karnal, Haryana, India - 132001

\section{Article history}

Received: 28 May, 2019

Revised : 29 Aug., 2019

Accepted: 31 Aug., 2019

\section{Citation}

Kumar S, G Sandhu, SS Yadav, V Pandey, Om Prakash, A Verma, S C Bhardwaj, R Chatrath and GP Singh 2019. Agro-morphological and molecular assessment of advanced wheat breeding lines for grain yield, quality and rust resistance. Journal of Cereal Research 11(2): 131-139 doi.org/10.25174/2249-4065/2019/90162

\section{*Corresponding author}

Email: kumarsatish227@gmail.com,

\begin{abstract}
The genetic gain for yield in wheat and other cereals has been known to be stagnating in recent years. Breeding wheat cultivars with increased genetic potential can contribute to meet at least half of the desired production increases. In this context we have developed some advanced wheat lines in our breeding program, which aims to utilize the untapped variability. We assessed a set of 60 diverse lines along with four commercial check varieties for various agro-morphological traits, grain quality and yield based and also the adaptability using molecular markers. Significant genotypic differences were observed for most of the grain quality and agro-morphological traits recorded, including grain yield. We could identify lines which have significantly higher grain yield. The diversity analysis carried out using the DNA markers could explain the variability for different traits in this set. This set of genotypes is thus a very useful source as far as enhancing the yield levels. The lines developed through the conventional breeding program were based on crosses between elite breeding lines and specific donors and hence might resulted in higher yield potential.
\end{abstract}

Keywords: Wheat, advance breeding lines, cluster analysis, grain quality, stripe rust production in the initial years of the Green Revolution it appears to have stabilized in recent times. The increased yield levels are mainly attributed to the improved semi dwarf wheats, which were released from the direct introductions from CIMMYT, crosses of exotic and local cultivars, spring and winter cross derivatives and the synthetic derivatives (Halford, 2006; Pingali, 2012).

The genetic gain for yield in wheat and other cereals has been known to be stagnating in recent years (Graybosch and Peterson, 2010; Fischer and Edmeades, 2010; Brisson et al., 2010; Grassini et al., 2013). Also various biotic and abiotic stresses are threatening to bring down the yield levels. The recently released wheat varieties are prone to the attack of new aggressive strains/races of yellow rust especially in Northern India. Wheat rusts have always 
posed a serious concern to wheat crop in this region. Unless tackled effectively, the threat of emerging new races of rusts could result in severe yield losses threatening national food security (Chaves et al., 2013). On the abiotic stress front terminal as well as early heat stress has been a concern in recent years and the wheat scenario in the country is aggravated due to higher temperature regime during crop growth period especially at grain filling. Wheat grain quality remains an area of concern as no specific breeding efforts are carried out to improve end use quality.

Breeding wheat cultivars with increased genetic potential can contribute to meet at least half of the desired production increases. Non conventional sources can be used in pre-breeding programs for broadening the gene pool for different yield component traits. Development of synthetics and utilization of winter wheats can pave way for wheat genotypes having high yielding ability. Hybrid wheat can also be assessed as an option for breeding for high yield potential. In this context we have developed some advanced wheat lines in our breeding program, which aims to utilize the untapped variability available in the germplasm and also through international collaborations. The genotypes developed after hybridization with diverse sources for yield attributing traits were subjected to rigorous screening against wheat rusts particularly stripe and leaf at various stages of development. In this study we evaluated these lines along with commercially grown wheat varieties, for yield, disease resistance and grain quality. Also we tried to assess the diversity of these lines based on some known molecular markers which were known to be associated with stripe rust resistance, photoperiod sensitivity and vernalization response.

\section{Materials and Methods}

Plant Materials: A set of 60 advanced wheat breeding lines and four check varieties namely, DBW90, HD2967, HD3086 and WH1105 were used. Experiment was conducted during 2016-17 in main cropping season at Indian Institute of Wheat and Barley Research, Karnal, India $\left(29.68^{\circ} \mathrm{N}, 76.99^{\circ} \mathrm{E}\right)$. The experiment was laid out in $8 \times 8$ lattices with a plot of 6rows of $6 \mathrm{~m}$ length and 20 $\mathrm{cm}$ apart. The genotypes were evaluated for agronomic traits such as, heading days (HD), maturity days (DM), plant height $(\mathrm{PH})$, number of tillers per meter, grain per spike, biomass, harvest index, 1000 grains weight and grain yield per plot.

2.1 Evaluation for stripe and leaf rusts: For adult plant resistance evaluation, stripe and leaf rusts were artificially created on the set of genotypes using a mixture of most prevalent races of both stripe (78S84, $46 \mathrm{~S} 119,111 \mathrm{~S} 68)$ and leaf $(77-5,77-9,104-3)$ rusts. The artificial epiphytotics were created using standard procedures on two different sets. The rust severity was recorded following the modified Cobb scale (Peterson et al. 1948). The diseases severity was assessed as resistant (free or 0 value), moderately resistant (upto10S), moderately susceptible (upto 40S) and susceptible (more than 40 S). Seedling resistance test was carried out for stripe rust using two most virulent and prominent pathotypes of Puccinia striiformis $f$ sp tritici (46S1149 and 110S119). Infection types were recorded two weeks after inoculation (Stakman et al., 1962) with some modifications.

2.2 Assessment of grain quality: The quality parameters measured on the harvested seeds of each genotype were: Grain appearance score, Hectolitre weight / test weight (Mishra, 1998), Sedimentation value (Axford et al.,1979), Phenol score, Protein and Moisture content (using whole grain analyzer Infratec 1241supplied by M/S Foss Analytical AB, Sweden). Micronutrient content for Iron (Fe) and Zinc (Zn) was estimated using, an X-ray inflorescence machine (XRF) Oxford Instruments X-Supreme 8000 (Paltridge et al., 2012).

2.3 Molecular marker analysis: For molecular marker analysis, fresh leaf material $(100 \mathrm{mg})$ of each genotype was cut and collected in $1.5 \mathrm{ml}$ eppendorf tube, to extract genomic DNA according to Riede and Anderson (1996). Finally the DNA was dissolved in 150 $\mathrm{\mu l}$ of 1XTE buffer and was incubated at room temperature for overnight. A total of 23 DNA based markers (URIC/LN2-F, xbarc8, STS-7/8, xgwm389, xgwm413, xbarc349, sun106, ppdB1a.2, vrnB1a, ZCCT1, ppdB1a.1(b), ppdB1a(b), ppdA1a.3, ppdA1a.1/2, ppdA1null, vrnA1(a), vrnA1(b), vrnB3, ppdB1a(a), ppdD1b.3, ppdD1null, ppdD1a, ppdD1a.1) already known to be associated with stripe rust resistance, photoperiod response and vernalization requirement were used to study the overall diversity present in this set of genotypes for these traits.

Polymerase chain reaction (PCR) was performed using a Thermal Cycler Life Eco (Bioer) PCR system. PCR products were separated by $2 \%$ agarose gel and were stained with Ethidium bromide.

2.4 Data analysis: Analysis of variance (ANOVA) was conducted to evaluate the variance and significance among genotypes for different traits. The grand mean, standard of error, and coefficient of variation were calculated as indicators of trait variability. The clustering analysis was performed with DARwin software ver 5.0 (Perrier and Jacquemoud-Collet, 2006). The allelic classes were used to calculate pairwise genetic distances with Nei's genetic distance matrix. 
Agro-morphological and molecular assessment of advanced wheat breeding lines for grain yield, quality and rust resistance

Table 1a: Analysis of variance (ANOVA) for the test lines and check varieties on various agro-morphological and yield traits

\begin{tabular}{lcccccccccc}
\hline $\begin{array}{l}\text { Source of } \\
\text { variation }\end{array}$ & DF & \multicolumn{10}{c}{ F-Value } \\
\cline { 2 - 12 } & & $\begin{array}{c}\text { Heading } \\
\text { Days }\end{array}$ & $\begin{array}{c}\text { Maturity } \\
\text { Days }\end{array}$ & $\begin{array}{c}\text { Height } \\
(\mathrm{cm})\end{array}$ & Tiller/m & Grain/Spike & $\begin{array}{c}1000 \\
\text { gr. Wt. }\end{array}$ & $\begin{array}{c}\text { Biomass } \\
\text { (g/plot) }\end{array}$ & $\begin{array}{c}\text { Harvest } \\
\text { index }\end{array}$ & $\begin{array}{c}\text { Yield } \\
(\mathrm{g} / \mathrm{plot})\end{array}$ \\
\hline Replications & 1 & $8.65 \mathrm{E}-01$ & $2.33 \mathrm{E}-01$ & $1.31 \mathrm{E}-01$ & $7.33 \mathrm{E}+00$ & $3.20 \mathrm{E}+00$ & $4.59 \mathrm{E}+00$ & $8.36 \mathrm{E}+00$ & $8.51 \mathrm{E}-01$ & $2.16 \mathrm{E}+00$ \\
Treatments & 63 & $4.29 \mathrm{E}+00$ & $5.03 \mathrm{E}+00$ & $3.63 \mathrm{E}+00$ & $1.77 \mathrm{E}+00$ & $1.75 \mathrm{E}+00$ & $2.20 \mathrm{E}+00$ & $1.51 \mathrm{E}+00$ & $2.20 \mathrm{E}+00$ & $2.41 \mathrm{E}+00$ \\
Error & 63 & $1.00 \mathrm{E}+00$ & $1.00 \mathrm{E}+00$ & $1.00 \mathrm{E}+00$ & $1.00 \mathrm{E}+00$ & $1.00 \mathrm{E}+00$ & $1.00 \mathrm{E}+00$ & $1.00 \mathrm{E}+00$ & $1.00 \mathrm{E}+00$ & $1.00 \mathrm{E}+00$ \\
\hline
\end{tabular}

Table 1b: Analysis of variance (ANOVA) for the test lines and check varieties on various grain quality traits

\begin{tabular}{|c|c|c|c|c|c|c|c|c|c|}
\hline \multirow{2}{*}{$\begin{array}{r}\text { Source of } \\
\text { variation }\end{array}$} & \multirow[t]{2}{*}{$\mathrm{DF}$} & \multicolumn{8}{|c|}{ F-Value } \\
\hline & & $\begin{array}{c}\text { Grain } \\
\text { Appearance Score }\end{array}$ & $\begin{array}{c}\mathrm{Fe} \\
(\mathrm{ppm})\end{array}$ & $\begin{array}{c}\mathrm{Zn} \\
(\mathrm{ppm})\end{array}$ & $\begin{array}{l}\text { Protein } \\
(\%)\end{array}$ & $\begin{array}{c}\text { Moisture } \\
(\%)\end{array}$ & $\begin{array}{l}\text { Test weight } \\
(\mathrm{Kg} / \mathrm{L})\end{array}$ & $\begin{array}{l}\text { Sedimentation } \\
\text { value }(\mathrm{cc})\end{array}$ & Phenol score \\
\hline Replications & 1 & $4.12 \mathrm{E}+00$ & $6.51 \mathrm{E}+00$ & $1.38 \mathrm{E}+00$ & $3.63 \mathrm{E}+01$ & $4.14 \mathrm{E}+01$ & $2.49 \mathrm{E}+00$ & $4.72 \mathrm{E}+00$ & $3.31 \mathrm{E}+01$ \\
\hline Treatments & 63 & $2.38 \mathrm{E}+00$ & $1.45 \mathrm{E}+00$ & $1.24 \mathrm{E}+00$ & $1.58 \mathrm{E}+00$ & $1.84 \mathrm{E}+00$ & $3.72 \mathrm{E}+00$ & $8.40 \mathrm{E}+00$ & $7.10 \mathrm{E}+00$ \\
\hline Error & 63 & $1.00 \mathrm{E}+01$ & $1.00 \mathrm{E}+01$ & $1.00 \mathrm{E}+01$ & $1.00 \mathrm{E}+00$ & $1.00 \mathrm{E}+00$ & $1.00 \mathrm{E}+00$ & $1.00 \mathrm{E}+00$ & $1.00 \mathrm{E}+00$ \\
\hline
\end{tabular}

\section{Results and Discussion}

Analysis of variance showed that significant genotypic differences were observed for most of the grain quality and agro-morphological traits recorded, including grain yield (Table 1a \& b). Many genotypes were either comparable to the check varieties or over performing for all the traits studied. Some of the genotypes evaluated in this study showed significantly superior plot yields than the check varieties, at $5 \%$ level of significance.

3.1. Evaluation for agro-morphological traits including grain yield: The mean performance of the genotypes and checks for different traits (table 2) is discussed below:

3.1.1. Days to heading (HD): The heading days ranged from 79 (G14) to 102 (G26, G36) days with an average of 93 days in the test lines. Among the checks, HD 3086 flowered in 89 days whereas HD 2967 took 95 days. Among the genotypes tested, the lines flowered early are G14 (79 days), G16 (85 days) and G18 (85 days). As many as 25 genotypes flowered earlier than the average days to flowering observed in the set.

3.1.2. Days to maturity (DM): The number of days required for the genotypes to attain maturity ranged from 130 (G15) to 143 (G11, G12, G36, G42) days with an average maturity of 136 days. More over among the checks, HD 3086 matured in 129.5 days whereas HD 2967 matured in 135.5 days. Hence we were able to identify genotypes with a maturity period more than the checks and thus these may get more degree days which may lead to enhanced yield.
3.1.3. Plant height (PH): The plant height in the set of genotypes ranged from $83 \mathrm{~cm}(\mathrm{G} 40)$ to $113 \mathrm{~cm}(\mathrm{G} 25)$ with an average height of $99 \mathrm{~cm}$. Among the checks the height was $96 \mathrm{~cm}$ in HD 3086 and 104cm in HD 2967. The preference of wheat genotypes with more height among the farmers is due to more biomass and straw yield requirements. However taller genotypes tend to lodge and hence a balance of height is required in the genotypes to be successful in commercial cultivation. 27 genotypes had plant height below the average value of the trial.

3.1.4. Number of tillers per meter: The number of productive tillers is one of the post important traits that determine the overall yield of wheat plant. The tiller number per meter in the set of genotypes ranged from 64 (G38) to 130 (G31) with a mean of 96. Among the checks, WH 1105 had highest tillers per meter (119) and DBW 90 had a value of 79 .

3.1.5. Number of grains per spike: The number of grains per spike is another important trait that contributes to the overall yield. Among the test genotypes, the range of grain number per spike was observed from 46 grains $(\mathrm{G} 14, \mathrm{G} 56)$ to 79 grains (G34) with an average of 58 grains per spike. Among checks, the number of grains per spike ranged from 46.5 in HD2967 to 66 in WH1105.

3.1.6. 1000 grains weight: The low estimate of 1000 grains weight was recorded as $30 \mathrm{~g}(\mathrm{G} 48)$ and the maximum of $46 \mathrm{~g}$ (G4) among the set of genotypes. HD 3086 had a mean 1000 grains weight of $43 \mathrm{~g}$ and HD 2967 recorded a value of 39g. 32 genotypes had 1000 grains weight above average. 


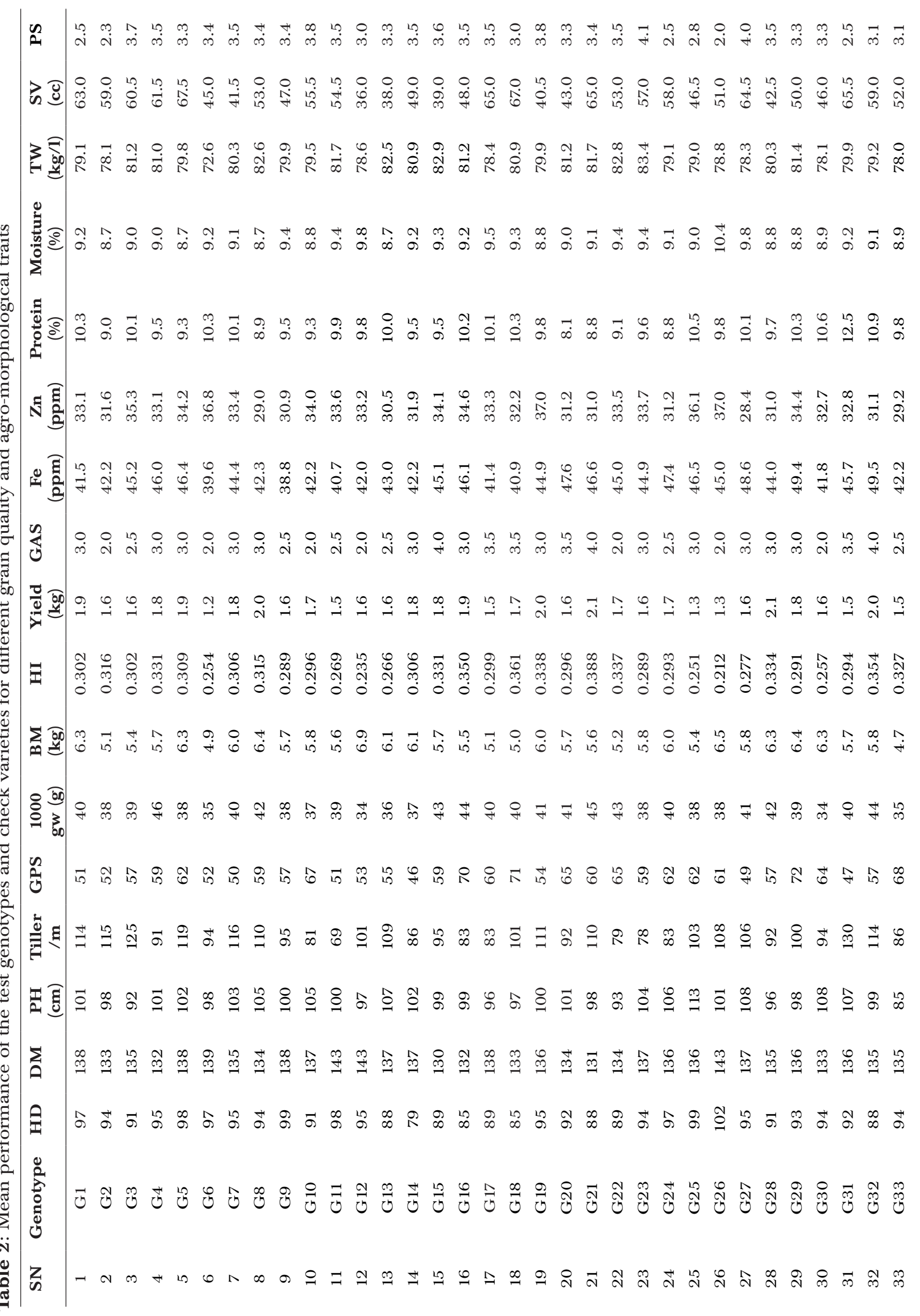




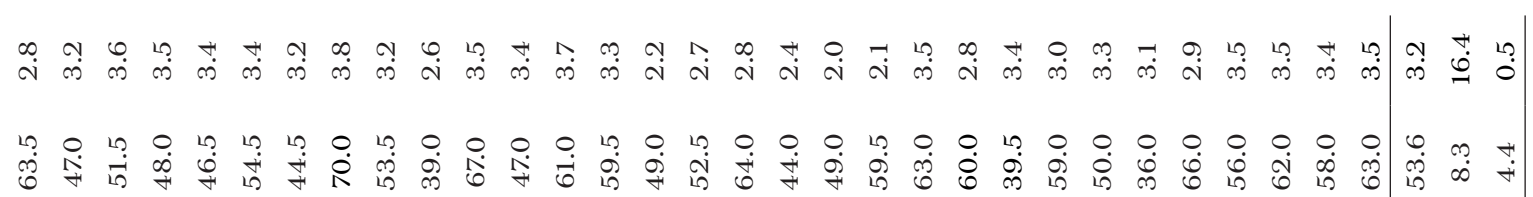

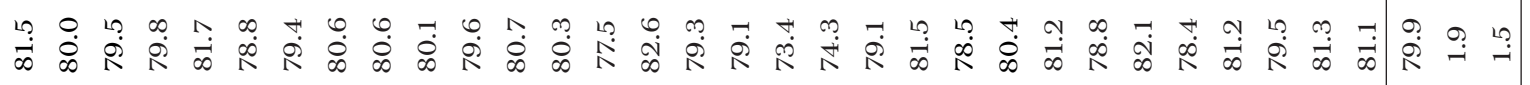



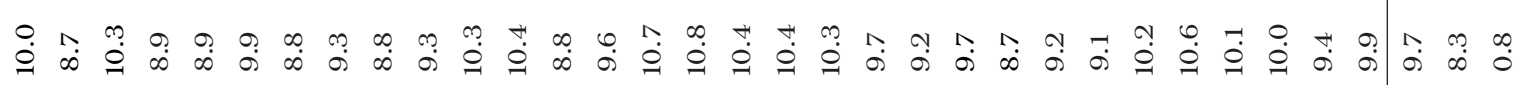

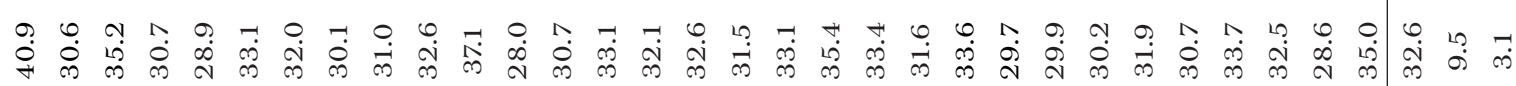

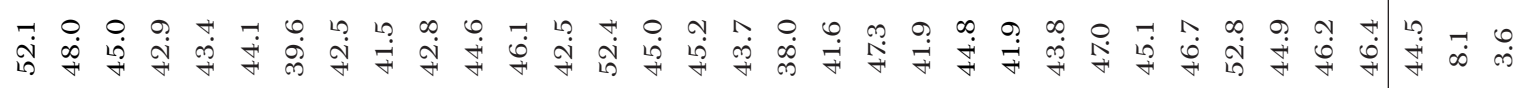

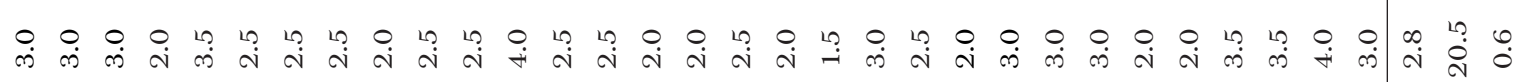

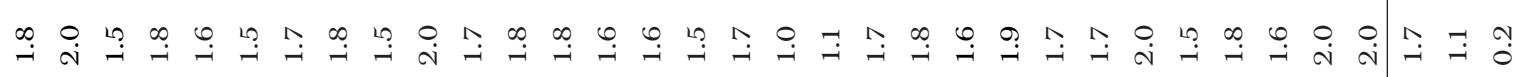

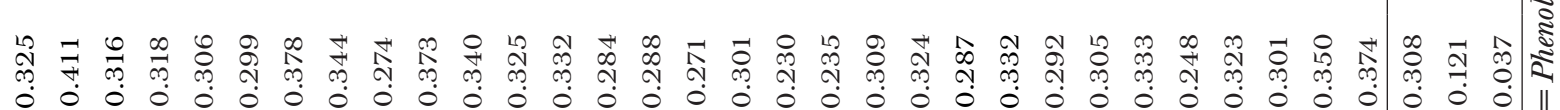

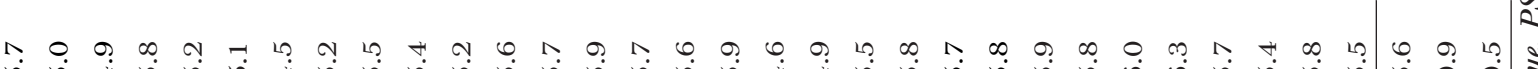
的

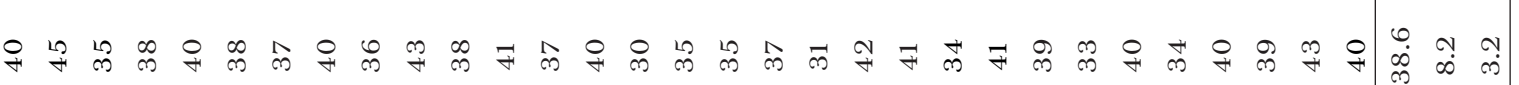

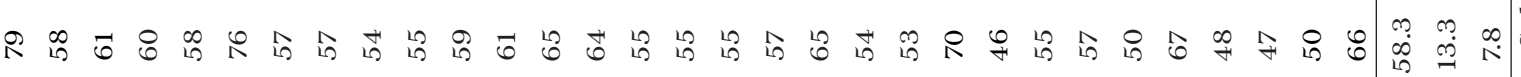

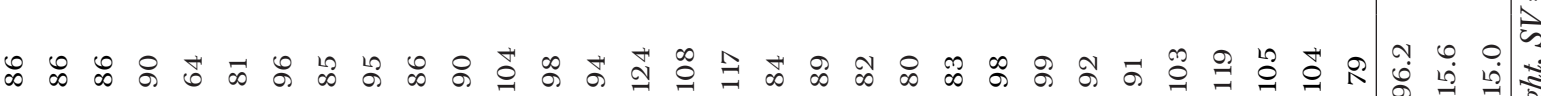

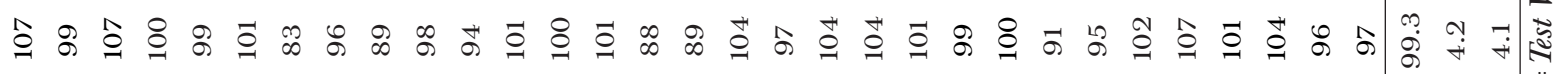

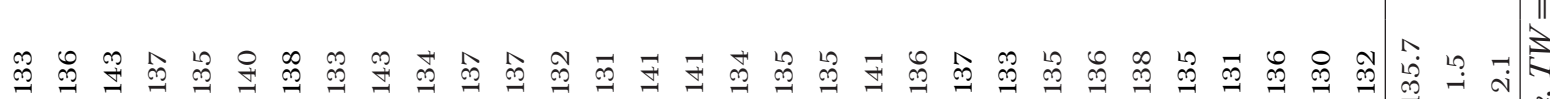

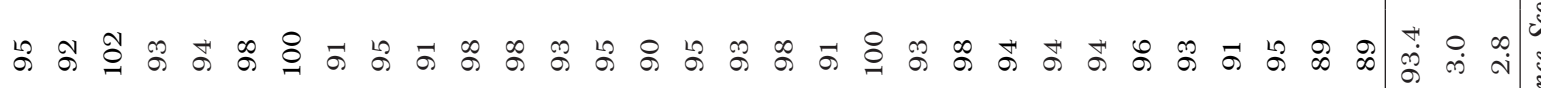

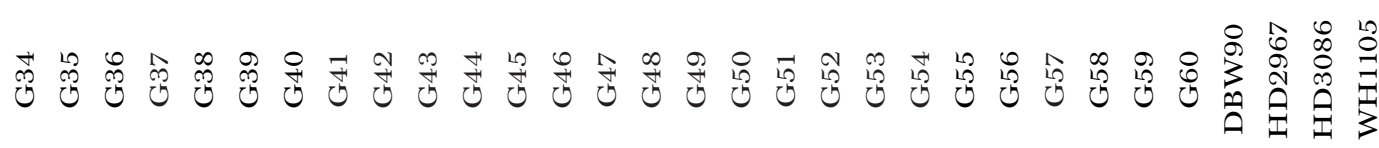

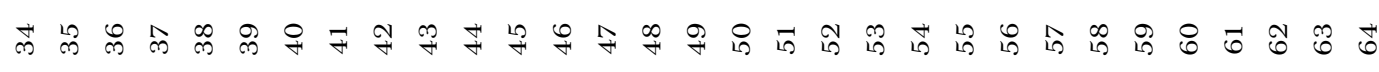


3.1.7. Biomass per plot: The range of the biomass observed in the set of genotypes was $4.5 \mathrm{~kg}(\mathrm{G} 40)$ to 6.9 $\mathrm{kg}(\mathrm{G} 12)$ whereas the mean biomass was recorded to be $5.6 \mathrm{~kg}$ per plot. Out of 4 checks, maximum biomass was recorded in HD $3086(5.8 \mathrm{~kg})$ whereas the minimum $(5.4 \mathrm{~kg})$ in HD 2967. The low biomass observed in the mega cultivar HD 2967 was due to high incidence of stripe rust.

3.1.8. Grain yield per plot: The values of grain yield per plot ranged from $1.0 \mathrm{~kg}$ (G51) to $2.1 \mathrm{~kg}$ (G21, G28) in the set of genotypes. The average grain yield per plot was observed to be $1.7 \mathrm{~kg}$. Further among the checks, maximum yield $(2.0 \mathrm{~kg})$ was reported in WH 1105 , whereas HD 2967 had the minimum $(1.6 \mathrm{~kg})$ grain yield. Several genotypes (G1, G4, G5, G7, G8, G14, G15, G16, G18, G19, G21, G22, G24, G28, G29, G32, G34, G35, G37, G41, G43, G44, G45, G46, G50, G54, G56, G58 and G59) had grain yield per plot above average.

3.1.9. Harvest index: Harvest index defines the efficiency by which a genotype is able to convert its biomass into the economic grain yield. A maximum harvest index of 0.41 (G35) and a minimum of 0.21 (G26) was observed in the set of genotypes. The average harvest index of the trial was 0.31 . Among the checks, WH 1105 (0.37) and HD 2967 (0.30) had the highest and lowest values for harvest index. 27 genotypes had harvest index above average.

Based on the morphological data, the elite lines such as G11, G12, G14, G18, G21, G24, G34, G35, G46, G58 recorded values in desirable direction for early heading, early maturity, high yield, harvest index, 1000 grain weight etc. These genotypes may be used as parents in breeding program. Agro-morphological traits such as days to heading, plant height, number of grains per spike and 1000 kernel weight are known to have a significant and positive relationship with grain yield (Tahmasebi et al., 2013; Eivazi et al., 2017). Information on diversity and relationship among the agro-morphological traits will be helpful to breeders in constructing their breeding populations or lines and implementing selection strategies.

3.2. Evaluation for grain quality traits: The mean performance of the genotypes and checks for different traits (table 2) is discussed below:

3.2.1. Grain appearance score (GAS): GAS defines overall quality of the wheat grain. Grains amber in colour with a shining luster are preferred and hence given a higher score on a scale of 1 to 5 . In the set of genotypes the score ranged from 1.5 (G52) to 4 (G15, G21, G32, G45) with a mean of 3. Among checks HD 3086 had a good grain appearance score of 4.0.

3.2.2. Protein and moisture content: The mean value of protein content for genotypes ranged from 8.1\% (G20) to $12.5 \%$ (G31) with a trial average of $10.0 \%$. Among checks, DBW 90 had the highest protein content of $10.12 \%$. The moisture content ranged from $8.4 \%(\mathrm{G} 40)$ to $10.4 \%(\mathrm{G} 26)$ in the genotypes. Maximum moisture content of $9.04 \%$ was reported in check variety HD 2967. Many genotypes had high protein content of more than $10.0 \%$.

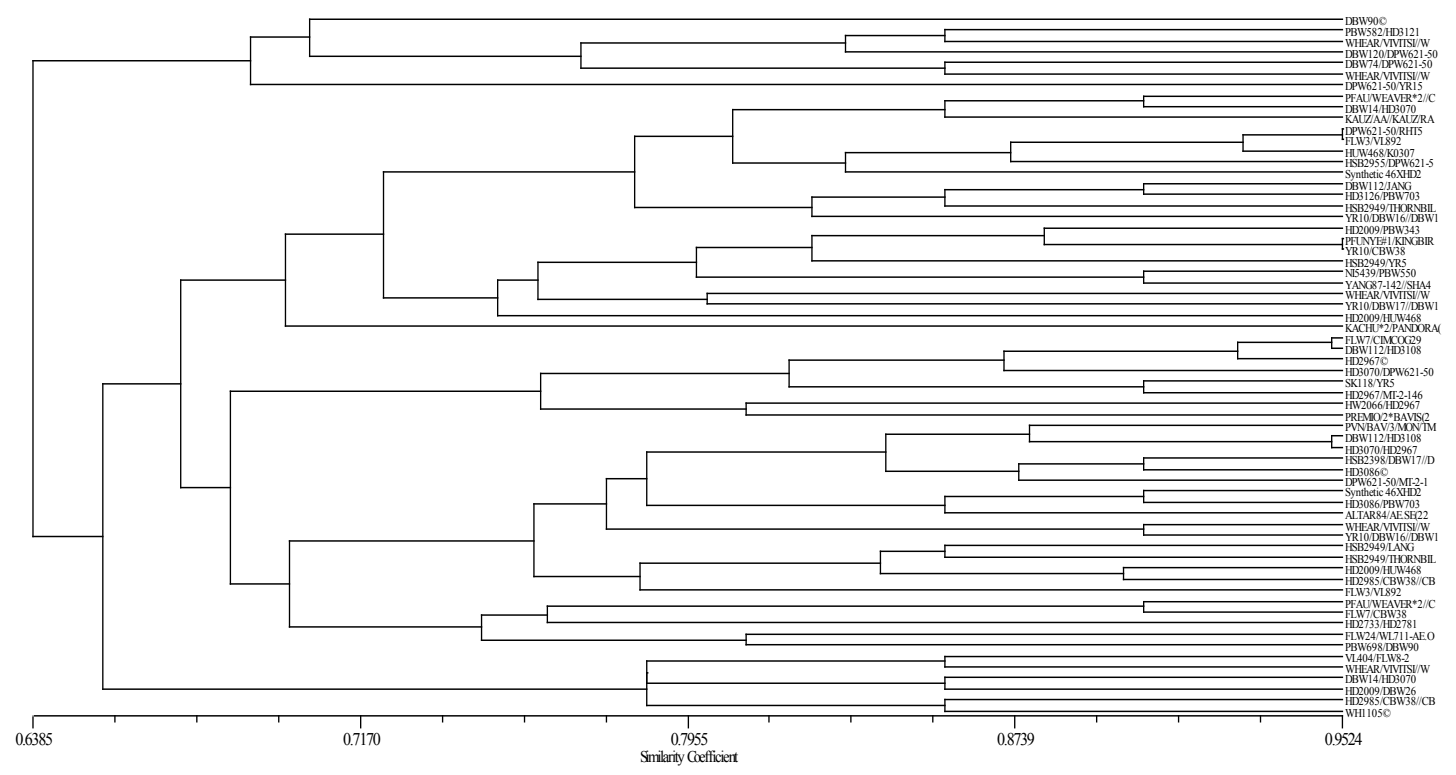

Fig 1: The graphical representations of the dissimilarity among studied 64 genotypes based on neighbor-joining method was generated by DARWIN 5 software. 
Agro-morphological and molecular assessment of advanced wheat breeding lines for grain yield, quality and rust resistance

Table 3: Genotypes and their pedigree details in each cluster as derived through DNA marker analysis

\begin{tabular}{|c|c|c|}
\hline Clusters & $\begin{array}{l}\text { Genotype } \\
\text { Number }\end{array}$ & Pedigree details \\
\hline \multicolumn{3}{|l|}{ Group A } \\
\hline \multirow{3}{*}{$\begin{array}{l}\text { Cluster } \\
\text { A1 }\end{array}$} & G16 & PFUNY\#1/KINGBIRD \# 1 \\
\hline & G23 & HD3070/DPW621-50 \\
\hline & G56 & $\begin{array}{l}\text { W H E A R / V IV I T S I / / W H E A R / } \\
\text { DBW17//DBW16 }\end{array}$ \\
\hline \multirow{24}{*}{$\begin{array}{l}\text { Cluster } \\
\text { A2 }\end{array}$} & G17 & KACHU*2/PANDORA \\
\hline & G25 & Synthetic46/HD2932 \\
\hline & G26 & $\begin{array}{l}\mathrm{PFAU} / \mathrm{WEAVER} * 2 / / \mathrm{CHAPIO} / \\
\text { DBW146 }\end{array}$ \\
\hline & G28 & $\begin{array}{l}\text { WHEAR/VIVIT S I / / W H E A R / } \\
\text { DBW17//DBW17 }\end{array}$ \\
\hline & G29 & YR10/DBW16//DBW16 \\
\hline & G30 & $\begin{array}{l}\text { FLW24/WL711-AE.OVATA/CS } \\
3^{*} \text { WL711 }\end{array}$ \\
\hline & G31 & HD2733/HD2781 \\
\hline & G35 & PREMIO/2*BAVIS \\
\hline & G36 & YR10/DBW17//DBW17 \\
\hline & G37 & HD2009/HUW468 \\
\hline & $\mathrm{G} 40$ & HSB2398/DBW 17//DBW17 \\
\hline & G41 & DPW621-50/YR15 \\
\hline & G42 & HSB2949/THORNBILL \\
\hline & G43 & $\begin{array}{l}\text { WHEAR/VIVIT S I / / W H E A R / } \\
\text { DBW17//DBW17 }\end{array}$ \\
\hline & G45 & DBW112/HD3108 \\
\hline & G50 & HD2985/CBW38//CBW38 \\
\hline & G51 & FLW3/VL892 \\
\hline & G52 & Synthetic-46/HD2932 \\
\hline & G54 & NI5439/PBW550 \\
\hline & G55 & VL404/FLW8-2 \\
\hline & G59 & $\begin{array}{l}\text { YANG } 87-142 / / \mathrm{SHA} 4 / \mathrm{CHIL} / 3 / \mathrm{TNMU} / \\
\text { DBW16 }\end{array}$ \\
\hline & G60 & HD2985/CBW38//CBW38 \\
\hline & DBW90 & Check \\
\hline & HD3086 & Check \\
\hline \multicolumn{3}{|l|}{ Group B } \\
\hline \multirow{8}{*}{$\begin{array}{l}\text { Cluster } \\
\text { B1 }\end{array}$} & G10 & HD3126/PBW703 \\
\hline & G21 & HD2967/PBW703 \\
\hline & G24 & HW2066/HD2967 \\
\hline & G33 & HD3086/PBW703 \\
\hline & G39 & DBW120/DPW621-50 \\
\hline & G49 & HSB2949/THORNBILL \\
\hline & G53 & YR10/CBW38 \\
\hline & G58 & HD2009/DBW26 \\
\hline
\end{tabular}

\begin{tabular}{|c|c|c|}
\hline \multirow{15}{*}{$\begin{array}{l}\text { Cluster } \\
\text { B2 }\end{array}$} & G2 & KAUZ/AA//KAUZ/RAJ3765 \\
\hline & G3 & DBW14/HD3070 \\
\hline & G4 & DPW621-50/Rht5 \\
\hline & G5 & HD2009/PBW343 \\
\hline & G6 & FLW3/VL892 \\
\hline & G7 & HUW468/K0307 \\
\hline & G8 & HSB2955/DPW621-50 \\
\hline & G14 & YR10/DBW16//DBW16 \\
\hline & G15 & $\begin{array}{l}\text { WHEAR/VIVITS I / / W H E A R / } \\
\text { DBW17//DBW17 }\end{array}$ \\
\hline & G20 & DBW74/DPW621-50 \\
\hline & G38 & DBW112/HD3108 \\
\hline & G44 & DPW621-50/PBW702 \\
\hline & G46 & HD2009/HUW468 \\
\hline & G47 & HD3070/HD2967 \\
\hline & WH1105 & Check \\
\hline \multicolumn{3}{|l|}{ Group C } \\
\hline \multirow{3}{*}{$\begin{array}{l}\text { Cluster } \\
\text { C1 }\end{array}$} & G1 & PFAU/WEAVER*2//CHAPIO/HD2009 \\
\hline & G12 & SK118/YR5 \\
\hline & G13 & HSB2949/YR5 \\
\hline \multirow{10}{*}{$\begin{array}{l}\text { Cluster } \\
\text { C2 }\end{array}$} & G9 & DBW112/JANG \\
\hline & G11 & FLW7/CIMCOG29 \\
\hline & G18 & PBW582/HD3121 \\
\hline & G19 & $\begin{array}{l}\text { WHE A R / VIVITS I / / W H E A R/ } \\
\text { DBW17//DBW16 }\end{array}$ \\
\hline & G22 & $\begin{array}{l}\mathrm{PVN} / \mathrm{BAV} / 3 / \mathrm{MON} / \mathrm{TMU} / \mathrm{ALD} / \\
\mathrm{PVN} / 4 / \mathrm{VEE} \# 5 / \mathrm{SARA} / \mathrm{DBW} 16 / / \\
\mathrm{DBBW} 16\end{array}$ \\
\hline & G27 & FLW7/CBW38 \\
\hline & G34 & $\begin{array}{l}\text { ALTAR } 84 / A E . S E(224) / / 2 * Y A C O / 3 / \\
\text { MILAN/CBW38//CBW38 }\end{array}$ \\
\hline & G48 & HSB2949/LANG \\
\hline & G57 & DBW 14/HD3070 \\
\hline & HD2967 & Check \\
\hline \multicolumn{3}{|l|}{ Group D } \\
\hline $\begin{array}{l}\text { Cluster } \\
\text { D1 }\end{array}$ & G32 & PBW698/DBW90 \\
\hline
\end{tabular}

3.2.3. Test weight (hectoliter weight): The range of the hectoliter weight recorded in the genotypes was $72.6 \mathrm{~kg} /$ $\mathrm{hl}(\mathrm{G} 6)$ to $83.4 \mathrm{~kg} / \mathrm{hl}$ (G23). The mean hectoliter weight was $80 \mathrm{~kg} / \mathrm{hl}$. Among checks, maximum hectoliter was recorded in genotype HD $3086(81.3 \mathrm{~kg} / \mathrm{hl})$.

3.2.4. Sedimentation value: The sedimentation value ranged from 36cc (G12, G59) to 70cc (G41) in the genotypes with an average of $54 \mathrm{cc}$. The maximum sedimentation value of $63 \mathrm{cc}$ was observed in the check variety $\mathrm{WH} 1105$. 
3.2.5. Phenol score: Phenol score gives an overall estimate of the grain quality and its suitability for specific end product. The phenol score ranged from $2.0(\mathrm{G} 26, \mathrm{G} 52)$ to $4.1(\mathrm{G} 23)$ in the set of genotypes with an average value of 3.0. Among check varieties HD 3086 had a minimum phenol score of 3.4.

3.2.6. Micronutrient content: The micronutrient content of the wheat grain defines industrial quality of the produce and is also important as far as nutritional quality of wheat is considered. Grain Iron $(\mathrm{Fe})$ and Zinc $(\mathrm{Zn})$ contents of the genotypes were estimated to determine the nutritional quality. The mean Iron content observed in the set was $44.0 \mathrm{ppm}$ with a range of $38.0 \mathrm{ppm}$ (G51) to $52.4 \mathrm{ppm}$ (G47) in the set of genotypes. Among checks DBW 90 had a high value of $52.8 \mathrm{ppm}$ Iron content. Zinc content in the set was $33.0 \mathrm{ppm}$ with a range of $28.0 \mathrm{ppm}$ (G45) to $40.9 \mathrm{ppm}$ (G34). Among the checks, a maximum $\mathrm{Zn}$ content of $34.95 \mathrm{ppm}$ was reported WH 1105. Wide variation for iron and Zinc has been reported by several authors in different studies (Graham et al., 1999; Morgounovet al., 2007; Rawat et al., 2008), but the availability of micronutrients in modern day varieties is partial.

3.3. Evaluation for wheat stripe and leaf rusts: The set of genotypes and the check varieties were evaluated for resistance to stripe and leaf rusts at both seedling and adult plant stages to determine the level of resistance (data not given).

3.3.1. Adult plant resistance (APR): For evaluation of APR against stripe and leaf rusts, artificially created epiphytotics were created separately at Karnal using a mixture of most prevalent and virulent races of the pathogen. Based on this screening it was observed that, for stripe rust, most of the advanced lines and the check varieties were resistant. Among the genotypes, nine lines (G2, G6, G10, G17, G22, G33, G44, G51 \& G52) and the variety HD 2967 had a reaction value of more than $40 \mathrm{~S}$ and hence were susceptible. Whereas, for leaf rust only one genotype (G15), was susceptible with a high score of more than $40 \mathrm{~S}$.

3.3.2. Race specific seedling resistance test (SRT): SRT was carried out in the set for stripe rust with two most virulent and prevalent pathotypes, 46S119 and 110S119. In case of $46 \mathrm{~S} 119$ trait, all the genotypes including checks showed resistance reaction. Only one line (G20) has found to be highly susceptible. Whereas for the most virulent pathotype 110S119, seventeen lines (G1, G6, G9, G14, G15, G17, G19, G22, G24, G32, G33, G38, G39, G45, G51, G53 \& G59 ) and the check variety HD 2967 were found to be highly susceptible.

3.4. Diversity analysis using molecular markers: $\mathrm{To}$ assess the diversity of these lines based on some known molecular markers which were known to be associated with stripe rust resistance, photoperiod sensitivity and vernalization response. The dendrogram generated (Fig 1) clearly indicates the clustering pattern of genotypes along with the checks. Based on DNA marker based diversity, the set was divided in to four major groups. First group included 27 genotypes, second group had 23 genotypes, third group had 13 genotypes and there was only one genotype in fourth group. The first three groups further had two major clusters each. Table 3 shows the list of genotypes in each cluster along with their pedigree details. The check varieties classified themselves into three different groups, with DBW 90 and HD 3086 being in one group. The genotype with G32 did not classify into any major group and thus was only constituent of the fourth group.

Evaluation of a set of advance wheat breeding lines along with the commercially grown wheat varieties for different agro-morphological and grain quality traits has led to identifications of lines which do not only have significantly higher grain yield but are also superior in various traits studied. The diversity analysis carried out using the DNA markers could explain the variability for different traits in this set. This set of genotypes is thus a very useful source as far as enhancing the yield levels. The lines developed through the conventional breeding program were based on crosses between elite breeding lines and specific donors and hence may have resulted in higher yield potential.

\section{Acknowledgements}

The authors acknowledge the contribution to this study through Institutional project at ICAR - IIWBR, Karnal.

\section{References}

1. Anonymous. 2019. Director's Report of AICRP on Wheat and Barley 2018-19, Ed: GP Singh. ICARIndian Institute of Wheat and Barley Research, Karnal, Haryana, India, 72p.

2. Asseng S, I Foster and NC Turner. 2011. The impact of temperature variability on wheat yields. Global Change Biology 17: 997-1012.

3. Axford D W E, E E McDermott and D G Redman. 1979. Note on the sodium dodecyl sulphate test of bread-making quality: Comparison with Pelshenke and Zeleny tests. Cereal Chemistry 56: 582-584.

4. Brisson N, P Gate, D Gouache, G Charmet, F X Oury and F Huard. 2010. Why are wheat yields stagnating in Europe? A comprehensive data analysis for France. Field Crop Research 119: 201-212. 
5. Chaves MS, JA Martinelli, C Wesp-Guterres, F AS Graichen, SP Brammer, SM Scagliusi, PR daSilva, P Wiethölter, GA M Torres, EY Lau, L Consoli and ALS Chaves. 2013. The importance for food security of maintaining rust resistance in wheat. Food Security 5:157-176.

6. Eivazi AR, M Rezaei, R Abdolazimazdeh and S Shiralizadeh. 2017. Evaluation of Wheat Promising Lines under On-Farm Conditions. Electronic Journal of Biology 13(3): 214-221.

7. FAO (2018) http://www.fao.org/3/a-i4691e.pdf

8. Fischer RA and GO Edmeades. 2010. Breeding and cereal yield progress. Crop Science 50: 585-598.

9. Graham RD, D Senadhira, S Beebe, C Iglesias and I Monasterio. 1999. Breeding for micronutrient density in edible portions of staple food crops conventional approaches. Field Crop Research 60: 57-80.

10. Grassini P, KM Eskridge and KG Cassman. 2013. Distinguishing between yield advances and yield plateaus in historical crop production trends. Nature Communications 4: 2918.

11. Graybosch RA and CJ Peterson. 2010. Genetic improvement in winter wheat yields in the great plains of North America, 1959-2008. Crop Science 50: 1882-1890.

12. Halford NG. 2006. From primitive selection to genetic modification, ten thousand years of plant breeding. In: Plant Biotechnology: Current and Future Applications of Genetically Modified Crops, Ed. N. Halford. London, UK: John Wiley \& Sons Ltd, 3-27p.

13. Mishra B K. 1998. Quality needs for Indian traditional products. In: Wheat: Research Needs Beyond 2000 A D.Narosa Publishing House, New Delhi.
14. Morgounov A, H F Gomez-Becerra, A Abugalieva, M Dzhunusova, M Yessimbekova, H Muminjanov, Y Zelenskiy, L Ozturk and I Cakmak. 2007. Iron and zinc grain density in common wheat grown in Central Asia. Euphytica 155: 193-203.

15. Paltridge NG, P J Milham., JI Ortiz-Monasterio, G Velu, Z Yasmin, LJ Palmer, GE Guild and J CR Stangoulis. 2012.Energy-dispersive X-ray fluorescence spectrometry as a tool for zinc, iron and selenium analysis in whole grain wheat. Plant and Soil 361:261-269.

16. Perrier X, Jacquemoud-Collet JP, (2006) DARwin software. .http,//www.darwin.cirad.fr/ darwin

17. Pingali P. 2012. Green Revolution: impacts, limits, and the path ahead. Proceedings of the National Academy of Sciences USA 109: 12302-12308.

18. Rawat N, VK Tiwari, N Singh, GS Randhawa, K Singh, P Chhuneja and HS Dhaliwal. 2008. Evaluation and utilization of Aegilops and wild Triticum species for enhancing iron and zinc content in wheat. Genetic Resource and Crop Evolution 56: 53-64.

19. Riede CR and JA Anderson. 1996. Linkage of RFLP markers to an aluminum tolerance gene in wheat. Crop Science 36: 905-909.

20. Stackman EC, DM Stewart and WQ Loegring. 1962. Identification of physiological races of Puccinia graminis var. tritici. Washington, USA: US Department of Agriculture, Agricultural Research Services, E617.

21. Tahmasebi G, J Heydarnezhadian and A Pour-Aboghadareh. 2013. Evaluation of yield and yield components in some of promising wheat lines. International Journal of Agriculture and Crop Science 5: 2379-2384. 